\title{
MAPPING OF SOIL MICRONUTRIENTS IN AN EUROPEAN ATLANTIC AGRICULTURAL LANDSCAPE USING ORDINARY KRIGING AND INDICATOR APPROACH (1)
}

\author{
JORGE DAFONTE DAFONTE (2,*); MONTSERRAT ULLOA GUITIÁN ( $\left.{ }^{3}\right)$; JORGE PAZ-FERREIRO (²); \\ GLÉCIO MACHADO SIQUEIRA $\left({ }^{4}\right)$; EVA VIDAL VÁZQUEZ ( $\left.{ }^{2}\right)$
}

\begin{abstract}
Nutrient maps based on intensive soil sampling are useful to develop site-specific management practices. Geostatistical methods have been widely used to determine the spatial correlation and the range of spatial dependence at different sampling scales. If spatial dependence is detected, the modelled semivariograms can then be used to map the interested variable by kriging, an interpolation method that produces unbiased estimates with minimal estimation variance. The objectives of this paper were to examine and to map the spatial distribution of the micronutrients $\mathrm{Cu}$, $\mathrm{Zn}, \mathrm{Fe}$ and $\mathrm{Mn}$ on an agricultural area in Galicia, Spain, under European Atlantic climatic conditions. The ordinary kriging was first used to determine the values for the non-sampled locations, then the indicator approach was used to transform the micronutrient content values into binary values having the mean values of each nutrient as the threshold content. All four elements analyzed showed spatial dependence using the indicator semivariograms. The strength of spatial dependence was assessed using the values of nugget effect and range from the semivariogram, the fitted range values decreased in the order $\mathrm{Mn}>\mathrm{Fe}>\mathrm{Zn}>\mathrm{Cu}$. The spatial dependence of the combination of two or more of the studied micronutrients was also examined using indicator semivariograms. In opposition to spatial analysis of individual microelements, indicator semivariograms obtained for the binary coding of the variables showed a great nugget effect value or a low proportion of sill. The maps for each nutrient obtained using indicator kriging showed some similarity in the spatial distribution, suggesting the delimitation of uniform management areas.
\end{abstract}

Key words: soil management; geostatistics; spatial variability; soil chemistry.

\section{RESUMO}

\section{MAPEAMENTO DE MICRONUTRIENTES DO SOLO DE UMA PAISAGEM AGRÍCOLA EUROPÉIA} ATLÂNTICA UTILIZANDO KRIGAGEM ORDINÁRIA E INDICATRIZ

\begin{abstract}
Mapas de nutrientes do solo com base em uma amostragem intensiva são úteis para desenvolver práticas específicas de manejo. Os métodos geoestatísticos cada vez mais têm sido utilizados para determinar a correlação espacial e o alcance da dependência espacial de amostragens em diferentes escalas. Uma vez detectada a variabilidade espacial, o semivariograma experimental é modelado e usado para mapear as variáveis investigadas por meio da krigagem, um método de interpolação sem tendência e com variância mínima. O objetivo deste trabalho foi avaliar e mapear a distribuição espacial dos micronutrientes $\mathrm{Cu}$, Zn, Mn e Fe em uma área agrícola, na Galícia, Espanha, sob condições climáticas do Atlântico Europeu. A krigagem ordinária foi aplicada inicialmente para se determinar os valores para os locais não amostrados. Posteriormente, a krigagem indicatriz foi utilizada para transformar o conteúdo de micronutrientes em valores binários, tendo os valores médios de cada nutriente como referência. Nos quatro micronutrientes estudados havia dependência espacial, expressa por meio dos parâmetros do semivariograma. A razão de dependência espacial foi avaliada por meio dos valores de efeito pepita e do alcance da dependência espacial, cuja dependência diminui na seguinte ordem $\mathrm{Cu}>\mathrm{Zn}>\mathrm{Fe}>\mathrm{Mn}$. A dependência espacial da combinação entre dois ou mais micronutrientes foi avaliada por meio do semivariograma indicador. De maneira geral, por meio da análise do semivariograma individual e do indicador notou-se baixa proporção entre os valores de efeito pepita e de patamar. Os mapas construídos por meio dos valores estimados com a krigagem indica triz demonstram semelhanças na distribuição espacial desses valores, o que sugere a delimitação de zonas de manejo.
\end{abstract}

Palavras-chave: manejo do solo; geoestatística; variabilidade espacial; química do solo.

( $\left.{ }^{1}\right)$ Received for publication in October 10, 2008 and accepted in August 24, 2010.

(2) University of Santiago de Compostela, Escuela Politécnica Superior, 27002, Lugo, Spain. * MAEC-AECID grant. E-mail: jorge.dafonte@usc.es. $\left(^{*}\right)$ Corresponding author.

(3) University of Coruña, Facultad de Ciencias, A Zapateira s/n, 15071, A Coruña, Spain. E-mail: evidal@udc.es; jpaz@udc.es

$\left(^{4}\right)$ Instituto Agronômico, Centro de Pesquisa e Desenvolvimento de Solos e Recursos Agroambientais, Av. Barão de Itapura 1481, 13020-902 Campinas (SP), Brasil. Bolsista FAPESP. E-mail: glecio@iac.sp.gov.br 


\section{INTRODUCTION}

The soil micronutrients have an important role in crop growth, and often they are present in small quantities in the soil. Micronutrients content in soil are dependent on the parent material, pedogenic process (WHITE and ZASOSKI, 1999), and soil management which may promote, in some cases, a reduction of cationic micronutrients content $(\mathrm{Cu}, \mathrm{Zn}, \mathrm{Fe}$ and $\mathrm{Mn}$ ) (Pegoraro et al., 2006).

The availability of micronutrients in agricultural soils is influenced mainly by: (a) soil with naturally low levels of micronutrients (b) reduction of the soil's natural fertility caused by the crop yield increment, (c) application of lime to soil reduces the availability of micronutrients, except molybdenum (ABREU et al., 1996; Ulloa Guittián et al., 2001; Pegoraro et al., 2006). Thus, the study of spatial variability of soil micronutrients content data promotes support to the rational management of soil with the objective of the sustainability of the agricultural environment.

Theinterest in soil spatial variability in agricultural sciences began at beginning of the 20th century (VIEIRA, 2000), when the effects of soil variability in grain yield was studied (SMITH, 1910; MONTGOMERY, 1913). MATHERON (1963) developed the theory of regionalized variables using KRIGE (1951) which concluded that the data variances depend on the separation distance between samples. Currently the application of geostatistics in agriculture has been used for the study of spatial variability of the most distinct attributes of soil and plant (McBratney, 1984; Couto and Klamt, 1999; Goovaerts, 1999; White and Zasoski, 1999; VieIra, 2000; CarvalHo and VieIRA, 2001; CARVAlHo et al., 2002; UlloA Guitián et al., 2002; LiU et al., 2004; GREGO and VIEIRA, 2005; MotomiYa et al., 2006; ZANÃo JúNIOR et al., 2007; SiqueIRA et al., 2008).

Carvalho and VieIRa (2001) emphasized that the study of spatial variability achieved through the analysis of the function of spatial covariance or semivariogram is not the final goal of spatial analysis, it must also estimate the values for unsampled locations. In that sense, VIEIRA et al. (2000) describe the technique of interpolation by kriging as a method for the estimation for unsampled locations without bias and with minimum variance.

Among the methods of interpolation by kriging, Carvalho and Vieira (2001) and Motomiya et al. (2006) reported the indicator kriging as a type of non parametric ordinary kriging, which uses the position and the values of any one attribute to produce a local distribution instead of a global distribution of the analyzed properties. For GOOVAERTS (1999), the indicator kriging is a method that allows spatializing the uncertainty of an attribute in an area of study, represented by the map of probability that this attribute exceed a certain critical or reference value. Indicator kriging determines, by using the samples in the neighborhood, the probability of data values in a given area being greater than a defined threshold value (ISAAKS and SRIVASTAVA 1989). To conduct indicator kriging, data values are transformed into indicator values: original values which exceed the chosen threshold value are coded 1 , and those below the threshold value are coded 0 . These indicators are then analyzed to determine their spatial variability with a series of experimental semivariograms.

Soil quality is the most important factor for sustaining the global biosphere. Soil quality may be defined in several different ways including productivity, sustainability, environmental quality, and effects on human nutrition. To quantify soil quality, specific soil indicators need to be measured spatially (SмIтH et al., 1993). These indicators are mainly soil properties whose values relate directly to soil quality but may also include policy, economic, or environmental considerations. Because assessing soil quality is complex, the individual soil quality indicators need to be integrated to form a soil quality index (SмIтH et al., 1993). Indicator kriging is widely used to map the probabilities of estimates that exceed given threshold levels such as regulatory thresholds of determined element in soil and environments parameters (ATKINSON and LLOYD, 1998; Carvalho and Vieira, 2001; Lin et al., 2002; Diodato and Ceccarelli, 2004; Tolosana-Delgado et al., 2005; Lyon et al., 2006; Мотомтүa et al., 2006; AssumpÇ̃̃o et al., 2007; Yu-PIN et al., 2010).

The objective of this study was to evaluate and to map the spatial distribution of soil micronutrients $(\mathrm{Cu}, \mathrm{Zn}, \mathrm{Fe}$ and $\mathrm{Mn})$, in an agricultural area in Galicia (Spain), under European Atlantic climatic conditions using ordinary kriging and indicator kriging for the analysis and construction of spatial variability maps.

\section{MATERIAL AND METHODS}

The study area is located in Abegondo (La Coruña, Spain). The geographical coordinates of the area are: latitude $43^{\circ} 12^{\prime} \mathrm{N}$ and longitude $8^{\circ} 18^{\prime} \mathrm{W}$. The study area has about 30 ha, and has a concave shape with an average elevation of $120 \mathrm{~m}$ (Figure 1), average slope of $6 \%$, with average annual temperature of $12.8 \mathrm{C}$ and average annual rainfall of $992 \mathrm{~mm}$. The soil types of the area are Cambisols and Umbrisols at the upper parts and Gleysols at the bottom, according to FAO classification (1998) (UlLOA GUITIÁN et al., 2001).

Table 1 shows the average for major chemical and physical characteristics for the study area, sampled at 0-0.3 m depth. At the time of sampling, $90 \%$ of the area was being cultivated with grassland and the rest of the 
a)

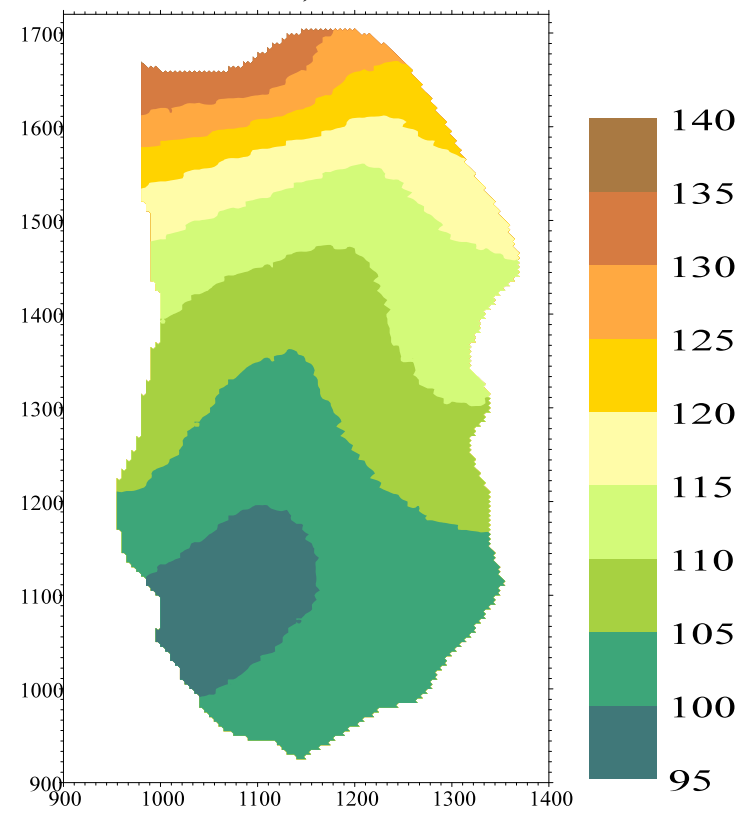

b)

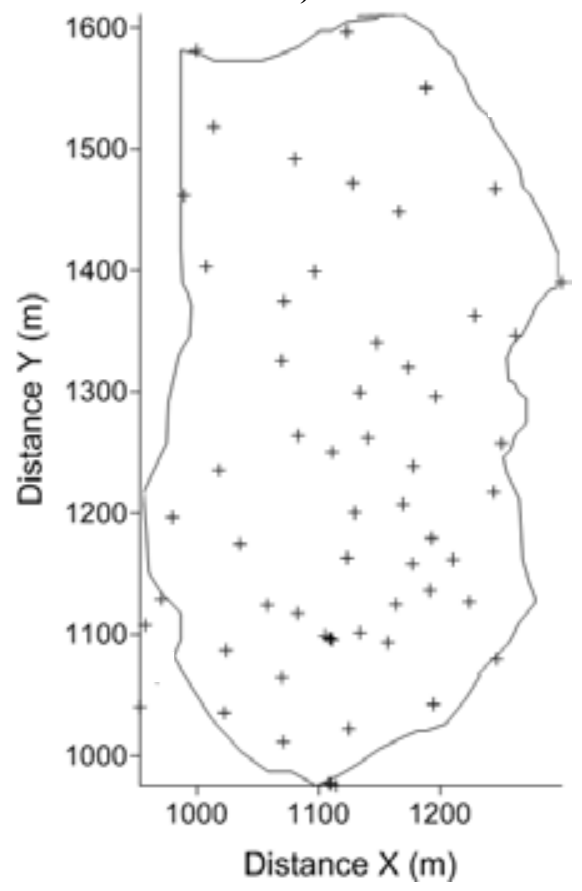

Figure 1. Elevation map (a) and location of soil sampling points (b).

Table 1. Mean $\mathrm{pH}$, organic matter (OM), sand, silt and clay contents of the study area

\begin{tabular}{|c|c|c|c|c|}
\hline $\mathrm{pH}(\mathrm{H} 2 \mathrm{O})$ & $\mathrm{OM}$ & Sand & Silt & Clay \\
\hline & $\%$ & ---------- & $-\mathrm{g} \mathrm{kg}-^{1}$ & ---------- \\
\hline 5.62 & 9.34 & 252.70 & 555.70 & 191.6 \\
\hline
\end{tabular}

area was in fallow after maize crop. The grassland area was divided into fields with different management, so that there were fields recently sowed, and others that were not renewed in the last ten years. Moreover, some of the fields were used for silage production, other as grazed fields and other fields with both uses (ULLOA GuITIÁN et al., 2001).

Samples were taken in the fall of 1996 at 0-0.3 m depth at 65 locations randomly distributed (Figure 1). The analyzed micronutrients were copper $\left(\mathrm{Cu}, \mathrm{mg} \mathrm{dm}^{-3}\right)$, zinc $\left(\mathrm{Zn}, \mathrm{mg} \mathrm{dm}^{-3}\right)$, iron $\left(\mathrm{Fe}, \mathrm{mg} \mathrm{dm}^{-3}\right)$ and manganese $\left(\mathrm{Mn}, \mathrm{mg} \mathrm{dm}^{-3}\right)$. The soil samples were collected with a dutch auger, air dried and sieved $(2 \mathrm{~mm})$. The content of $\mathrm{Cu}, \mathrm{Zn}, \mathrm{Fe}$ and $\mathrm{Mn}$ was determined using DTPA extraction solution: DTPA $0,005 \mathrm{~mol} \mathrm{~L}^{-1}+$ TEA $0.1 \mathrm{~mol}$ $\mathrm{L}^{-1}+\mathrm{CaCl}_{2} 0.01 \mathrm{~mol} \mathrm{~L}^{-1}$ at $\mathrm{pH} 7.3$, according to LINDAY and Norvell (1978). A volume of $10 \mathrm{~cm}^{3}$ of soil $+20 \mathrm{~mL}$ of extraction solution were used, stirring for 2 hours. To determine the values of $\mathrm{Cu}, \mathrm{Zn}, \mathrm{Fe}$ and $\mathrm{Mn}$ an atomic emission spectrometer by induced plasma (ICP-AES), model JY 50P (Jobin Yvon ${ }^{\circledR}$ ) was used.

The statistical analysis was performed using the software STAT (VIEIRA et al., 2002) which provided the main statistical moments (mean, median, minimum value, maximum value, standard deviation, coefficient of variation, skewness, kurtosis and normality of data was tested using Kolmogorov-Smirnov with $1 \%$ of normality. The analysis for detecting outliers values was made using equation 1 such as described by CAHN et al. (1994).

$$
\text { Outlier }_{\max / \min }=\bar{X} \pm 4 \sigma
$$

where: $\bar{X}$ - mean; $\sigma$-standard deviation.

The linear correlation coefficient between the different parameters was also determined. The critical limits of micronutrients contents (availability and toxicity), as proposed by RAIJ et al. (1996) and AlLowAY (1995) for elements extracted with DTPA are shown in table 2.

The data spatial variability analysis was performed using geostatistical tools, to estimate the fitting semivariogram parameter, according to VIEIRA et al. (2000) using cross validation, whereas all the attributes were under the intrinsic hypothesis of geostatistics (ChILÉs and Delfiner, 1999; VIEIRA, 2000). For 
Table 2. Critical limits of micronutrients in the soil.

\begin{tabular}{lcccc}
\hline \multirow{2}{*}{ Content } & \multicolumn{4}{c}{ Micronutrients $\left(\mathrm{mg} \mathrm{dm}^{-3}\right)$} \\
$\mathrm{Cu}$ & $\mathrm{Fe}$ & $0.0-1.29$ & $0.0-0.59$ \\
\hline Low* & $0.0-0.29$ & $0.0-4.9$ & $1.3-5.9$ & $0.6-1.29$ \\
Mean* & $0.3-0.89$ & $5.0-12.9$ & $5.1-9.9$ & $1.3-2.39$ \\
High* & $0.9-1.59$ & $13.0-24.9$ & $10.0-50.0$ & $2.4-15.9$ \\
Too high* & $1.6-15.9$ & $25.0-60.0$ & - & $>130.0$ \\
Toxic** & $>50.0$ & - & - & \\
\hline
\end{tabular}

* VAN Raij et al. (1996); ** Alloway (1995).

the analysis of the spatial variability of micronutrients the experimental semivariograms were calculated using the Equation 2:

$$
\gamma^{*}(h)=\frac{1}{2 N(h)} \sum_{i=1}^{N(h)}\left[Z\left(x_{i}\right)-Z\left(x_{i}+h\right)\right]^{2}
$$

where: $\gamma^{*}(h)$ is experimental semivariance, $N(h)$ represents the number of pairs of measured values $Z\left(x_{\mathrm{i}}\right)$, $Z\left(x_{\mathrm{i}}+h\right)$ separated by a vector $(h)$. In geostatistics, $Z\left(x_{\mathrm{i}}\right)$ is described as regionalized variable (VIEIRA, 2000). Thus, experimental semivariance values were determined using the software AVARIO (VIEIRA et al., 2002). The semivariogram model was fitted with the validation method "Jack-knifing" using the software JACK (VIEIRA et al., 2002). For the model fitting to the experimental semivariograms the following models were considered: spherical, exponential and Gaussian as suggested by VIEIRA (2000).

The spatial dependence (SD) between samples was also determined considering the relationship between the nugget effect $\left(\mathrm{C}_{0}\right)$ and sill $\left(\mathrm{C}_{0}+\mathrm{C}_{1}\right)$ expressed in percentage: $0-25 \%$ high, $25-75 \%$ medium and $75-100 \%$ low spatial dependence between samples, as proposed by CAMBARDELLA et al. (1994).

The indicator kriging (GOOVAERTS, 1999; CARVALHO and VIEIRA, 2001) was used considering the mean value of each of the micronutrients studied like threshold value for processing binary ( 0 to 1 ) the content of $\mathrm{Cu}, \mathrm{Zn}, \mathrm{Fe}$ and $\mathrm{Mn}$ in soil, thus promoting the combination between pairs of micronutrients $(\mathrm{Cu}+\mathrm{Zn}, \mathrm{Cu}+\mathrm{Fe}, \mathrm{Cu}+\mathrm{Mn}, \mathrm{Zn}+\mathrm{Fe}$, $\mathrm{Zn}+\mathrm{Mn}, \mathrm{Fe}+\mathrm{Mn}$ and $\mathrm{Zn}+\mathrm{Cu}+\mathrm{Fe}+\mathrm{Mn})$. Indicator kriging estimates the probability of exceeding specific threshold values at a given location. In this study the median value of the data was used since the data showed lognormal distribution $\left(Z_{\text {median }}\right)$. In indicator kriging, the data, $Z\left(x_{\mathrm{i}}\right)$, is transformed into an indicator as follows:

$$
i\left(x, Z_{\text {median }}\right)=\left\{\begin{array}{c}
1, \text { if } Z(X i) \leq Z_{\text {median }} \\
0, \text { otherwise }
\end{array}\right.
$$

The transformation of the original data on values of probability was held as follows: the values lower than the median value were assigned 0 values and values equal or greater than mean value were transformed into 1 . Subsequently, the combination was conducted between pairs of micronutrients, a combination of nutrients with the values of 0 and 1 received a numerical value equal to 0 , and the combination of micronutrients with values equal to 1 received a numerical value equal to 1 , so it was possible to make a second geostatistical analysis through a binary combination between micronutrients as described above.

It is known that the use of indicator kriging favors the loss of information. However it is noteworthy that this loss of information is compensated by determining a threshold considered of importance for studies of spatial variability, enabling the inclusion of additional information in the spatial analysis process.

The kriging technique was used to estimated the values for non-sampled places in the field without trend and with minimum variance (VIEIRA, 2000) using the software KRIGE (VIEIRA et al., 2002). The spatial variability maps were constructed using the software SURFER 7.0 (GOLDEN SOFTWARE, 1999).

\section{RESULTS AND DISCUSSION}

The main statistical moments for soil micronutrients are showed in Table 3. The coefficient of variation values $(\mathrm{CV})$ indicate high variability of $\mathrm{Cu}$, $\mathrm{Zn}, \mathrm{Fe}$ and Mn content, ranging from 42.7 to $50 \%$. Based on the coefficient of variation GOMES and GARCIA (2002) proposed the classification: $\leq 10 \%$ low, $10-20 \%$ medium; $20-30 \%$ high and $\geq 30 \%$ very high. At the study area, the soil management may be contributing to the great variability of the data, because fertilizers distribution is not very homogeneous. This fact causes a modification over the natural spatial variability of soil elements. The values of $\mathrm{CV}$ increase in the following order: $\mathrm{Fe}<\mathrm{Cu}<\mathrm{Zn}<\mathrm{Mn}$. ULLOA GUITIÁN et al. (2001) studying the availability of soil macro and micronutrient extracted with Mehlich-3 in the same area, found similar values of CV.

According to CARvalHo et al. (2002) values of skewness and kurtosis close to 0 and 3 respectively, are indicative of a normal frequency distribution. Manganese 
Table 3. Statistical parameters of micronutrients in the soil

\begin{tabular}{|c|c|c|c|c|c|c|c|c|c|c|c|c|}
\hline \multirow{2}{*}{ Micronutrient } & \multirow{2}{*}{ Unit } & \multirow{2}{*}{ Mean } & \multirow[t]{2}{*}{ Median } & \multicolumn{2}{|c|}{ Value } & \multicolumn{2}{|c|}{ Outlier } & \multirow{2}{*}{ SD } & \multirow{2}{*}{ CV (\%) } & \multirow{2}{*}{ Skewness } & \multirow{2}{*}{ Kurtosis } & \multirow{2}{*}{ d } \\
\hline & & & & Min. & Max. & Min. & Max. & & & & & \\
\hline $\mathrm{Cu}$ & \multirow{4}{*}{$\mathrm{mg} \mathrm{dm}^{-3}$} & 1.08 & 1.10 & 0.21 & 2.09 & -1.08 & 3.24 & 0.54 & 50.2 & 0.18 & 1.81 & $0.1276 \mathrm{Ln}$ \\
\hline $\mathrm{Zn}$ & & 0.65 & 0.59 & 0.18 & 2.03 & -0.71 & 2.01 & 0.34 & 51.9 & 1.52 & 6.31 & $0.1269 \mathrm{Ln}$ \\
\hline $\mathrm{Fe}$ & & 71.29 & 66.14 & 31.89 & 229 & -50.55 & 193.13 & 30.46 & 42.7 & 2.22 & 11.95 & $0.0997 \mathrm{Ln}$ \\
\hline $\mathrm{Mn}$ & & 49.33 & 39.85 & 8.04 & 130.7 & -65.15 & 163.81 & 28.62 & 58 & 0.94 & 3.23 & $0.1733 \mathrm{Ln}$ \\
\hline
\end{tabular}

Min.: minimum; Max.: maximum; SD: standard deviation; CV: coefficient of variation; d: normality of the date for test of Kolmogorov-Smirnov with $1 \%$ of normality

a) $\mathrm{Cu}$

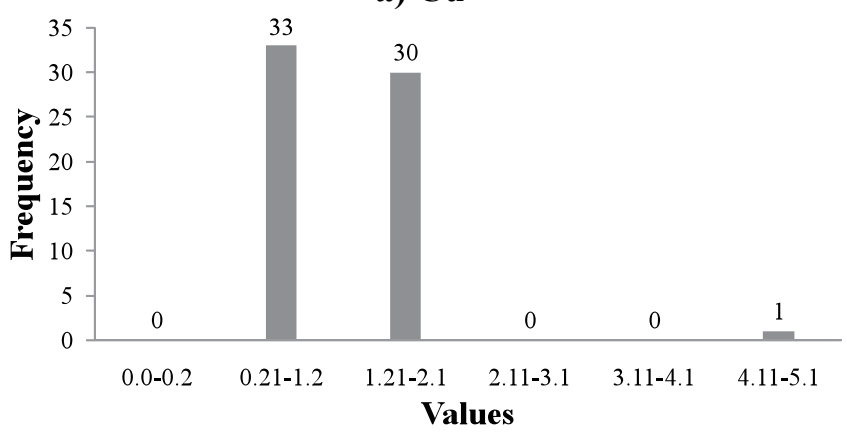

c)

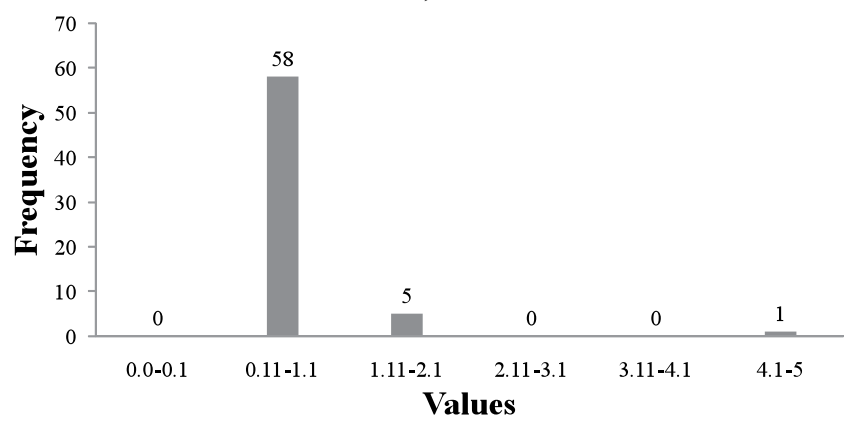

b)

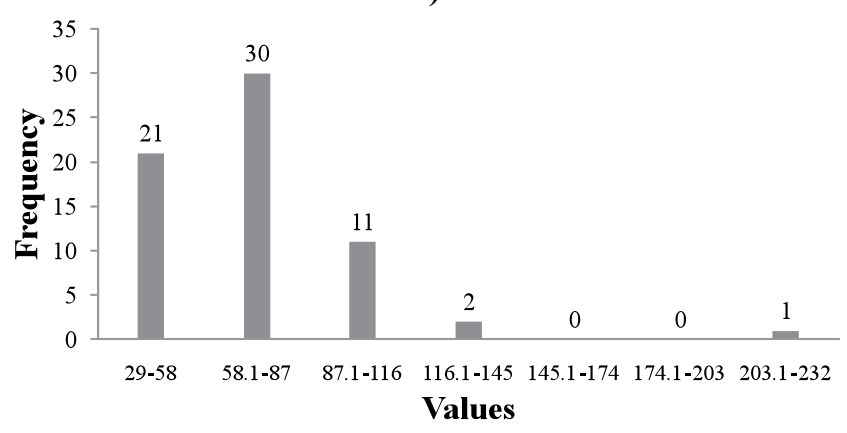

d)

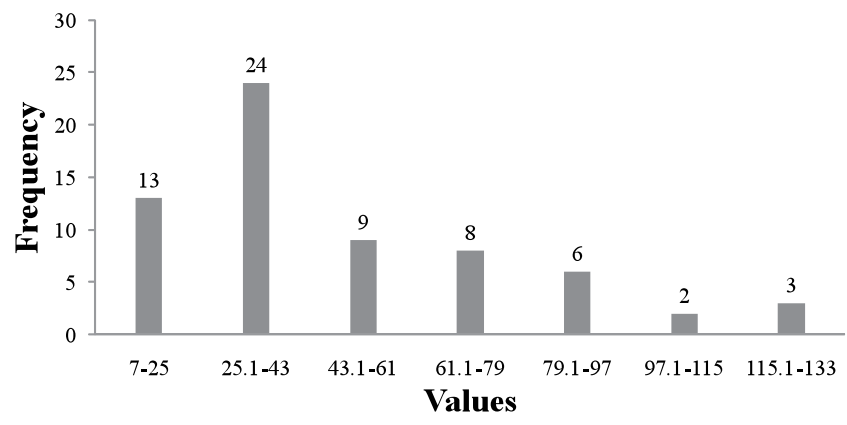

Figure 2. Frequency distribution for micronutrients in study: (a) $\mathrm{Cu},(\mathrm{b}) \mathrm{Fe},(\mathrm{c}) \mathrm{Zn}$ and (d) $\mathrm{Mn}$.

$(\mathrm{Mn})$ is the only attribute that has a normal frequency distribution. The analysis of frequency distribution histograms (Figure 2) show that Copper $(\mathrm{Cu})$ and Zinc $(\mathrm{Zn})$ have frequency distribution near to normal, although these elements show a long tails caused by the presence of minimum and maximum extreme values. On the other hand, the normality test of Kolmogorov-Smirnov with error probability of $1 \%$ (Table 3 ) shows that all the variables have a log-normal distribution.

The analysis of outliers in the study area (Table 3 ) show that only Zinc (Zn) has a value of $2.03 \mathrm{mg} \mathrm{dm}^{-3}$ greater than the outlier limit of $2.01 \mathrm{mg} \mathrm{dm}^{-3}$. The statistical analysis shows that the coefficient of variation values (CV, \% - Table 3) are very high $(\geq 30 \%)$ using the classification of GOMES and GARCIA (2002), caused by the soil management used in the study area.
For the mean data values $\left(\mathrm{mg} \mathrm{dm}^{-3}\right.$, Table 3$)$ it can be noted that cooper $(\mathrm{Cu})$ content is considered low according to the classification of VAN RAIJ et al. (1996) (Table 2). The zinc $(\mathrm{Zn})$ value is medium and iron $(\mathrm{Fe})$ and manganese $(\mathrm{Mn})$ are considered very high. Note that the mean value of Fe exceeds by about $10 \%$ the upper limit of classification of vAN RAIJ et al. (1996), however, Alloway (1995) do not describe Fe content toxic for the crops.

The linear correlation data is showed in Table 4. It appears that $\mathrm{Cu}$ content correlates in more than $50 \%$, with Zn, Fe and Mn content (Cu-Zn: 0.537, Cu-Fe: 0.529 and $\mathrm{Cu}-\mathrm{Mn}: 0.618$ ). The linear correlation between the $\mathrm{Zn}$ Fe content and $\mathrm{Zn}-\mathrm{Mn}$ is less than $50 \%$ (0.485 and 0.403, respectively). The correlation between Fe-Mn was not significant at $1 \%$ probability. UlLOA GUITIÁN et al. (2001) 
studied the linear correlation between micronutrients extracted with Mehlich-3 and found a correlation greater than $50 \%$ for the same micronutrients studied here.

The parameters for the models fitted to the semivariograms are shown in Table 5. The Gaussian model was fitted to the semivariograms of $\mathrm{Cu}, \mathrm{Zn}$ and $\mathrm{Mn}$, and the exponential model was fitted to the one for Fe. Other authors have reported the spherical model as the one that most used in semivariograms of soil and plant attributes (CAMBARDELLA et al., 1994; GReGo and VIEIRA, 2005; SiqueIRA et al., 2008). However, LIU et al. (2004) and ZANÃo JúNIOR et al. (2007) describe the exponential model as the one mostly used for soil micronutrients.

Nugget effect $\left(\mathrm{C}_{0}\right)$ values were low ranging from $0.00-0.022$. Low values of nugget effect $\left(C_{0}\right)$ indicate

Table 4. Correlation coefficient among of micronutrients in the soil

\begin{tabular}{lllll}
\hline & $\mathrm{Cu}$ & $\mathrm{Zn}$ & $\mathrm{Fe}$ & $\mathrm{Mn}$ \\
\hline $\mathrm{Cu}$ & 1.00 & & & \\
$\mathrm{Zn}$ & $0.537 *$ & 1.00 & 1.00 & \\
$\mathrm{Fe}$ & $0.529 *$ & $0.485^{*}$ & $* *$ & 1.00 \\
$\mathrm{Mn}$ & $0.618^{*}$ & $0.403^{*}$ & & \\
\hline
\end{tabular}

* significant (1\% probability); ** not significant.

Table 5. Fitted semivariogram models for the attributes

\begin{tabular}{lcccccccc}
\hline Micronutrient & Model & $\mathrm{C}_{0}$ & $\mathrm{C}_{1}$ & $\mathrm{a}$ & $\mathrm{RSS}$ & $\mathrm{r}^{2}$ & & ---------- SD ---------- \\
\hline $\log \mathrm{Cu}$ & Gaussian & 0.00 & 0.075 & 100 & 0.001115 & 0,848 & 0.00 & High \\
$\log \mathrm{Zn}$ & Exponential & 0.002 & 0.03 & 150 & 0.000325 & 0.719 & 6.25 & Medium \\
$\log \mathrm{Fe}$ & Gaussian & 0.022 & 0.025 & 150 & 0.000395 & 0.709 & 46.80 & Mediun \\
$\log \mathrm{Mn}$ & Gaussian & 0.017 & 0.055 & 135 & 0.001333 & 0.775 & 23.61 & Medium \\
\hline
\end{tabular}

$\mathrm{C}_{0}$ : nugget effect; $\mathrm{C}_{1}$ : structural variance; a: range $(\mathrm{m})$; RSS: residual sums of squares; $\mathrm{r}^{2}$ : correlation coefficient; SD: spatial dependence $(\%)$.

a)

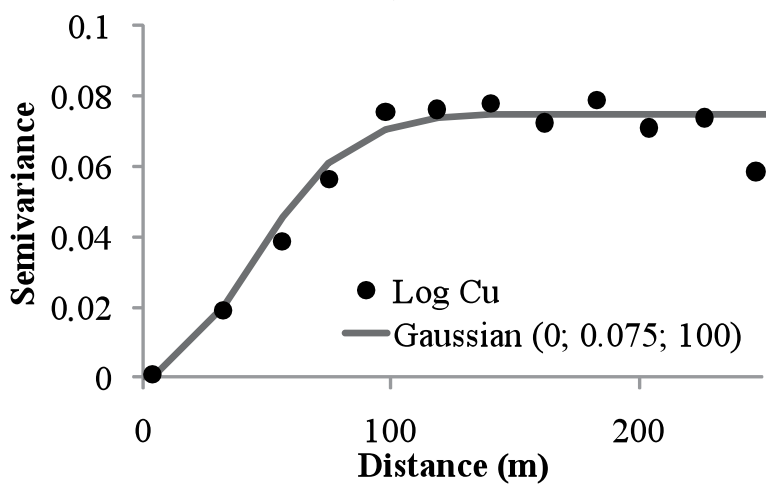

c)

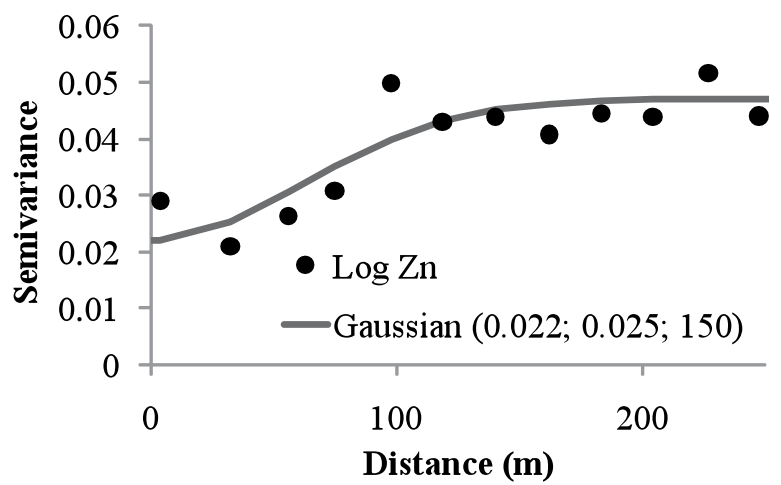

b)

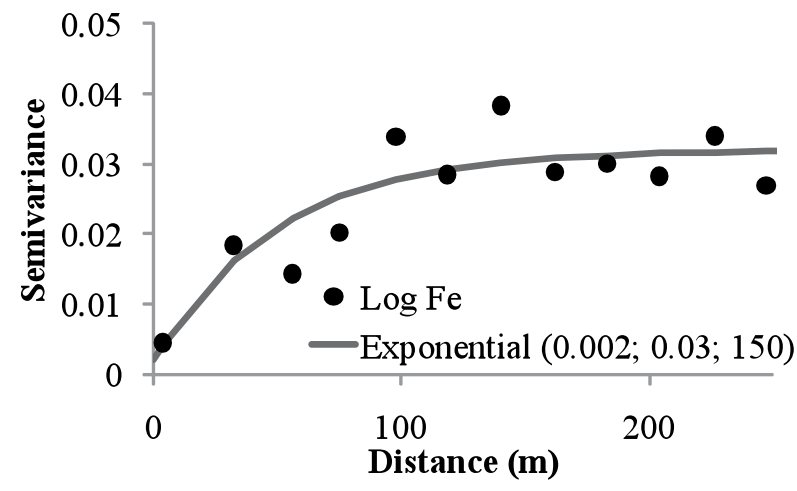

d)

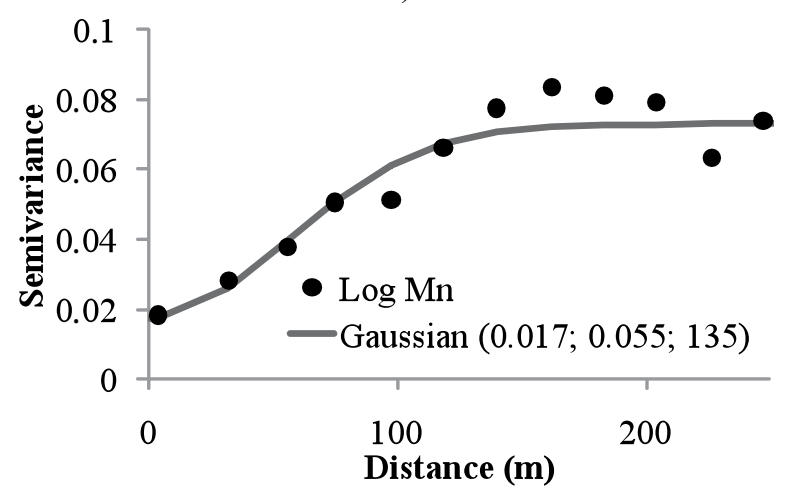

Figure 3. Experimental and fitted semivariogram model for micronutrients in the soil: a) Cu; b) Fe; c) Zn and d) Mn. 
low errors in measurements (VIEIRA, 2000). The values of the ranges (a) are similar for all micronutrients. The semivariograms for $\mathrm{Cu}$ and $\mathrm{Mn}$ (Table 5) presented a range value (a) of $100 \mathrm{~m}$ and $135 \mathrm{~m}$, respectively. The other attributes showed range values of $150 \mathrm{~m}$ (Fe and $\mathrm{Zn}$ ). The range values found represent an increase of 100 $\%$ with respect to the values found by ZANÃO JúNIOR et al. (2007) studying the spatial variability of micronutrients in a Ferralsol at different depths. On the other hand, COUTO and KLAMT (1999) studying the spatial variability of $\mathrm{Cu}, \mathrm{Zn}$ and $\mathrm{Mn}$ content in a Ferralsol at 0.0-0.2 $\mathrm{m}$ and 0.2-0.4 depth found range values around $450 \mathrm{~m}$.
The spatial dependence (SD, Table 5) for soil $\mathrm{Cu}$ content is strong according to the classification proposed by CAMBARDElla et al. (1994). The other micronutrients ( $\mathrm{Zn}, \mathrm{Fe}$ and $\mathrm{Mn}$ ) show moderate spatial dependence between samples.

The analysis of Figure 3 allows the inference that although there are differences between nugget effect $\left(\mathrm{C}_{0}\right)$ and structural variance values $\left(C_{1}\right)$, the semivariogram has a similar shape for $\mathrm{Zn}$ and Mn. However, this fact is not observed on spatial variability maps obtained with ordinary kriging (Figure 4). The greatest similarity a) $\mathrm{Cu}\left(\mathrm{mg} \mathrm{kg}^{-1}\right)$

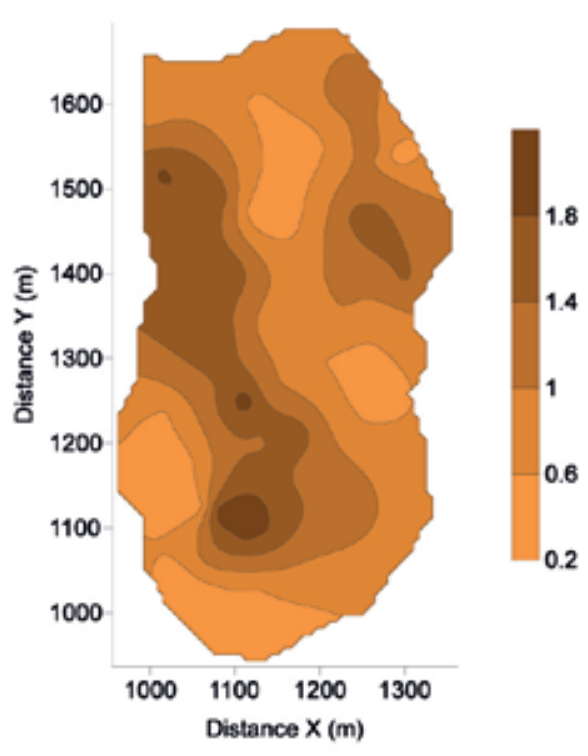

c) $\mathrm{Zn}\left(\mathrm{mg} \mathrm{kg}^{-1}\right)$

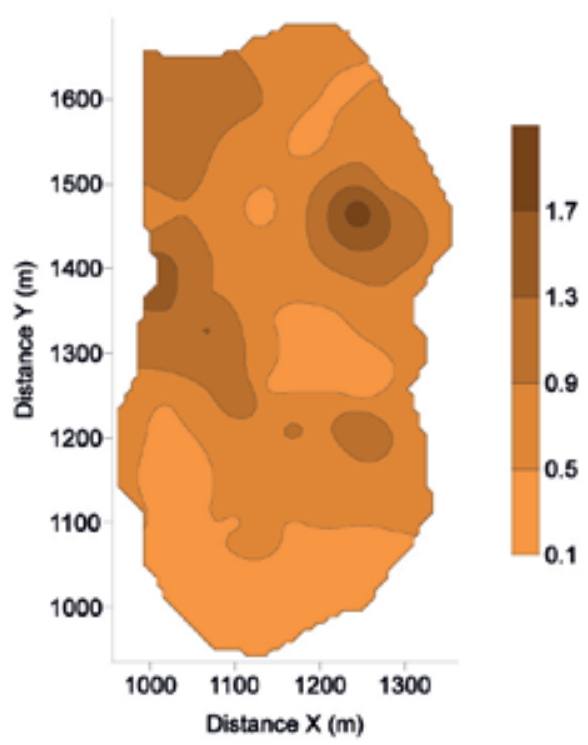

b) $\mathrm{Fe}\left(\mathrm{mg} \mathrm{kg}^{-1}\right)$

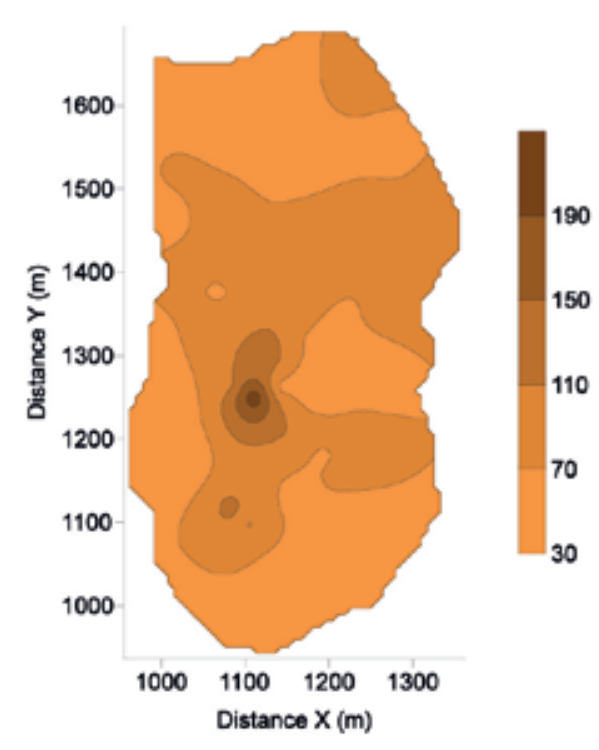

d) $\mathrm{Mn}\left(\mathrm{mg} \mathrm{kg}^{-1}\right)$

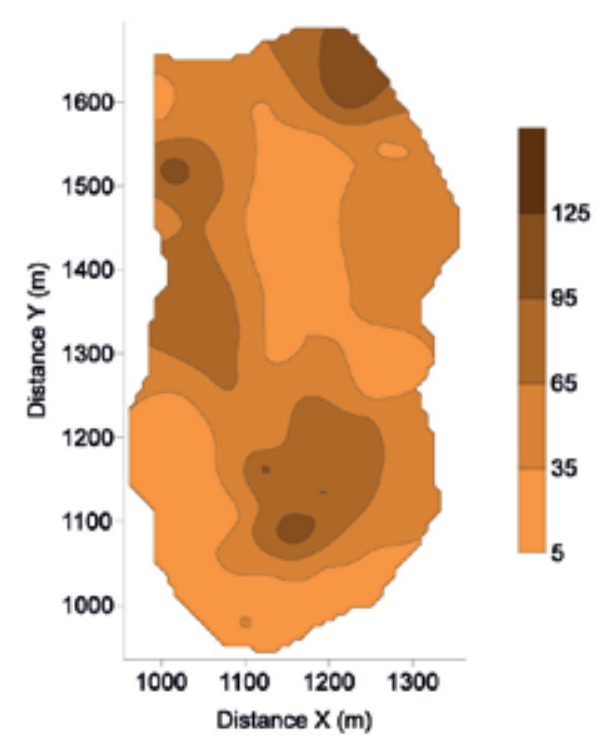

Figure 4. Map of the estimated values obtained by ordinary kriging. 
of pattern of spatial variability maps occurs between $\mathrm{Cu}$ and $\mathrm{Mn}$ content, and these two elements have the highest linear correlation value (Table 4). In general, it is observed larger concentration of $\mathrm{Cu}$ and $\mathrm{Mn}$ in the upper left area following this trend to the bottom right area. It appears that the maps show spatial distribution areas well defined, without trend and with smoothness.

The study using indicator kriging with the combination of micronutrients (Table 6) shows that not all interactions between micronutrients showed spatial dependence, showing pure nugget effect $(\mathrm{Zn}+\mathrm{Fe}, \mathrm{Fe}+\mathrm{Mn}$ and $\mathrm{Zn}+\mathrm{Cu}+\mathrm{Fe}+\mathrm{Mn})$. CAMBARDELLA et al. (1994) described that the pure nugget effect is an important phenomenon and indicates spatial random distribution, and may be due to measurement errors and/or microvariation not detected with the sample separation used. The combination of $\mathrm{Cu}+\mathrm{Zn}$ were fitted to exponential model (Table 6). The spherical model was used for the combination of $\mathrm{Cu}+\mathrm{Fe}$ and $\mathrm{Zn}+\mathrm{Mn}$, and the gaussian model for the combination of $\mathrm{Cu}+\mathrm{Mn}$.

Nugget effect values $\left(C_{0^{\prime}}\right.$ Table 6$)$ are low for all combinations of micronutrients with detected spatial variability pattern $(\mathrm{Cu}+\mathrm{Zn}, \mathrm{Cu}+\mathrm{Fe}, \mathrm{Cu}+\mathrm{Mn}$ and $\mathrm{Zn}+\mathrm{Mn})$. The combination of micronutrients showed range values from 120 to $190 \mathrm{~m}$. The lowest nugget effect value was found for the combination of $\mathrm{Cu}+\mathrm{Fe}(0.00)$, followed by $\mathrm{Cu}+\mathrm{Mn}$ (0.04), $\mathrm{Cu}+\mathrm{Zn}(0.07)$ and $\mathrm{Zn}+\mathrm{Mn}(0.07)$.

Range values (a, Table 6) varied in the following order: $\mathrm{Cu}+\mathrm{Zn}(120 \mathrm{~m}), \mathrm{Cu}+\mathrm{Mn}(130 \mathrm{~m}), \mathrm{Zn}+\mathrm{Mn}(152)$ and $\mathrm{Cu}+\mathrm{Fe}(190 \mathrm{~m})$. Spatial dependence ratio (SD) between samples using the classification proposed by CAMBARDELla et al. (1994) shows that the combination of $\mathrm{Cu}+\mathrm{Fe}(0.00 \%)$ and $\mathrm{Cu}+\mathrm{Mn}(13.79 \%)$ exhibitstrong spatial dependence between samples. The other combinations showed medium spatial dependence ratio $(\mathrm{Zn}+\mathrm{Mn}$ : $28.00 \%$ and $\mathrm{Zn}+\mathrm{Cu}: 30.43 \%$ ). Spatial dependence ratio (SD) between the micronutrients combinations follows the same pattern of linear correlation (Table 4) The combinations between micronutrients that have the highest spatial dependence ratio (SD), also have the highest values of linear correlation. As exception there is the interaction between $\mathrm{Cu}+\mathrm{Zn}$, which has the second highest simple linear correlation coefficient, however, it has moderate spatial dependence ratio (SD). On the other hand, it should be pointed that even with high correlation coefficient (Table 4) between $\mathrm{Cu}$ and $\mathrm{Zn}$ contents, the maps of spatial variability of these elements (Figure 4) do not have the same pattern in contour lines distribution.

The semivariograms for the combination of $\mathrm{Cu}+\mathrm{Fe}$ and $\mathrm{Cu}+\mathrm{Mn}$ (Figure 5) have different models fitted (spherical and gaussian, respectively), but have a similar shape. The same does not occur for other combinations $(\mathrm{Cu}+\mathrm{Zn}$ and $\mathrm{Zn}+\mathrm{Mn})$. The maps of spatial variability for the combination of micronutrients (Figure 6) indicate the existence of different patterns for contour lines distribution, not favoring the delimitation of specific management areas.

The analysis of micronutrients combination maps obtained with indicator kriging (Figure 6) using like threshold the micronutrients content average value shows that the probability map of $\mathrm{Cu}+\mathrm{Zn}$ presents an opposite behavior when compared with the original data (Figure 4). Areas with greater content of $\mathrm{Cu}$ and $\mathrm{Zn}$ (Figure 4) are not necessarily the same areas where the occurrence of values equal to or above the average for these elements are greater for the values obtained by kriging (Figure 6). The same fact occurs with the maps of the $\mathrm{Cu}+\mathrm{Fe}, \mathrm{Cu}+\mathrm{Mn}$ and $\mathrm{Zn}+\mathrm{Mn}$ indicators combination when compared with the spatial variability maps of the original values (Figure 4). Мотоміүa et al. (2006) studying the use of indicator kriging for the study of different soil chemical attributes also found an inverse relationship between the occurrence of original values and the combined probability occurrence of the reference value. Thus, the construction of combination elements indicator maps is important because it promotes a better management of agricultural areas considering the spatial variability which was not considered before.

The use of indicator kriging favors the mapping of different agricultural production factors, and promotes a better understanding of the attributes interaction

Table 6. Fitted indicator semivariogram models for of micronutrients in the soil

\begin{tabular}{|c|c|c|c|c|c|c|c|c|}
\hline Micronutrient & Model & $\mathrm{C}_{0}$ & $\mathrm{C}_{1}$ & $\mathrm{a}$ & RSS & $\mathrm{r}^{2}$ & \multicolumn{2}{|c|}{-------- SD --------- } \\
\hline $\mathrm{Cu}+\mathrm{Zn}$ & Exponential & 0.07 & 0.16 & 120 & 0.001617 & 0.699 & 30.43 & Medium \\
\hline $\mathrm{Cu}+\mathrm{Fe}$ & Spherical & 0.00 & 0.25 & 190 & 0.002823 & 0.952 & 0.00 & High \\
\hline $\mathrm{Cu}+\mathrm{Mn}$ & Gaussian & 0.04 & 0.25 & 130 & 0.008158 & 0.879 & 13.79 & High \\
\hline $\mathrm{Zn}+\mathrm{Fe}$ & \multicolumn{8}{|c|}{ Pure nugget effect } \\
\hline $\mathrm{Zn}+\mathrm{Mn}$ & Spherical & 0.07 & 0.18 & 152 & 0.006079 & 0.787 & 28.00 & Medium \\
\hline $\mathrm{Fe}+\mathrm{Mn}$ & \multicolumn{8}{|c|}{ Pure nugget effect } \\
\hline $\mathrm{Cu}+\mathrm{Zn}+\mathrm{Fe}+\mathrm{Mn}$ & & & & Pure & t effect & & & \\
\hline
\end{tabular}

$\mathrm{C}_{0}$ : nugget effect; $\mathrm{C}_{1}$ : structural variance; a: range $(\mathrm{m})$; RSS: residual sums of squares; $\mathrm{r}^{2}$ : correlation coefficient; SD: spatial dependence $(\%)$. 


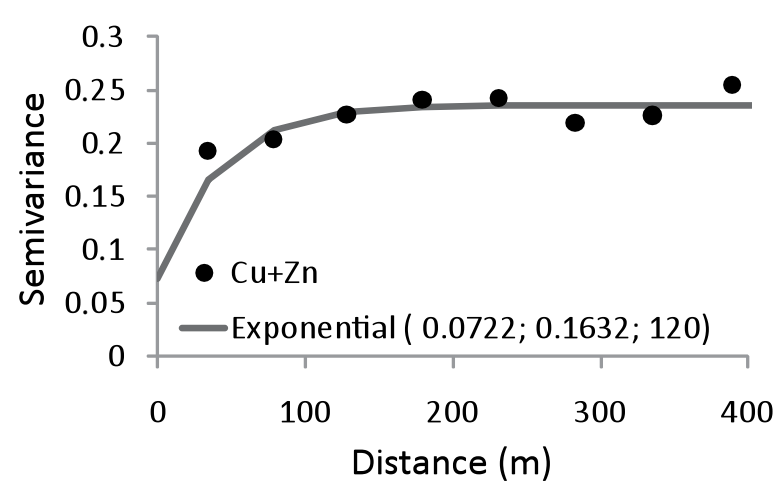

c)

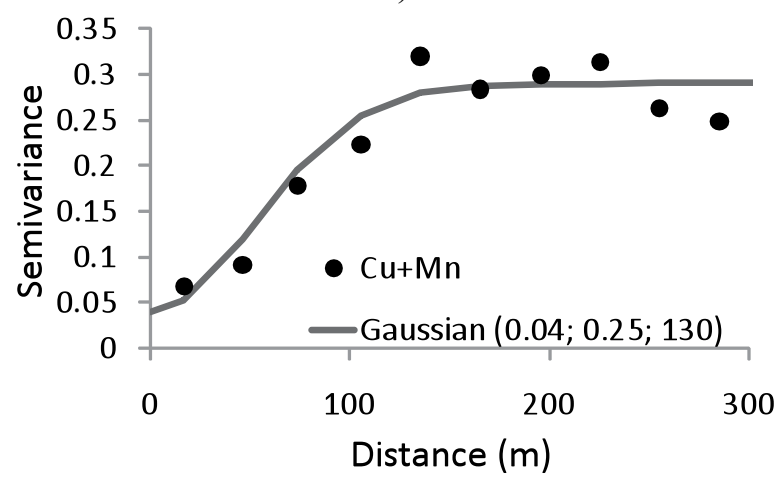

e)

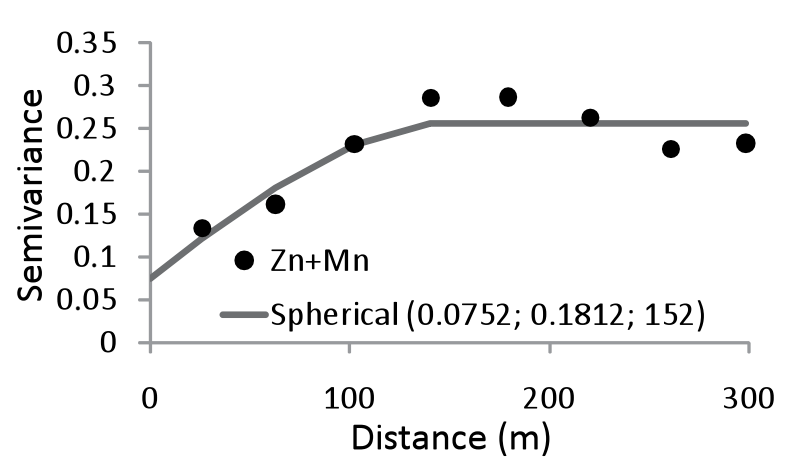

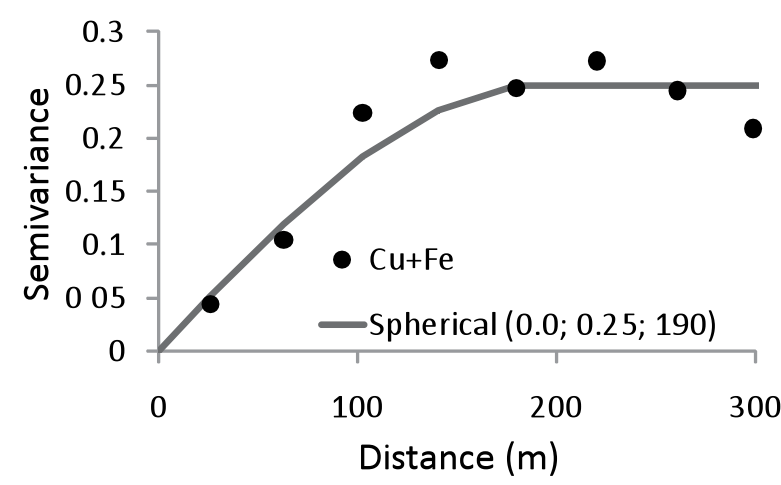

d)

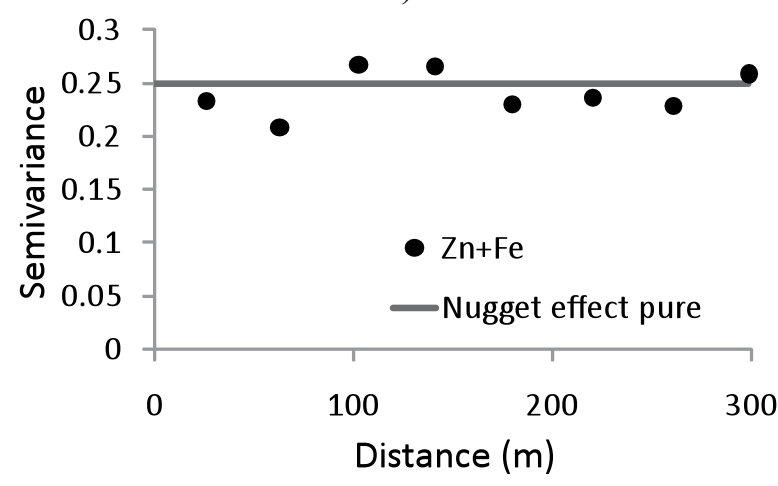

f)

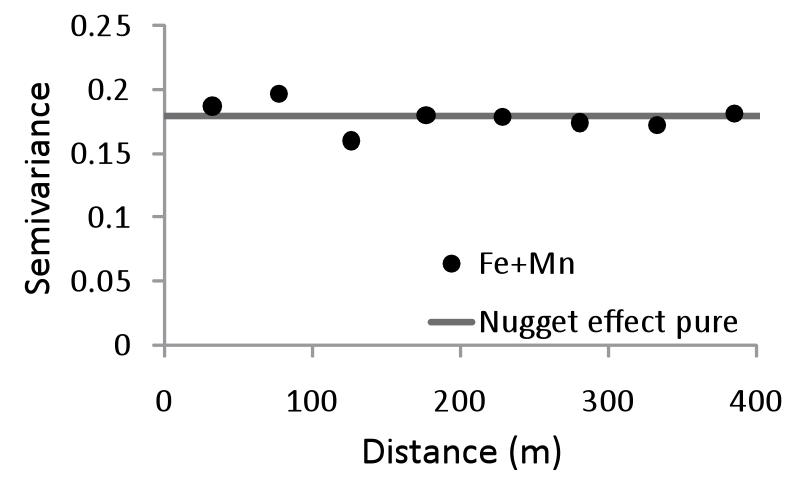

g)

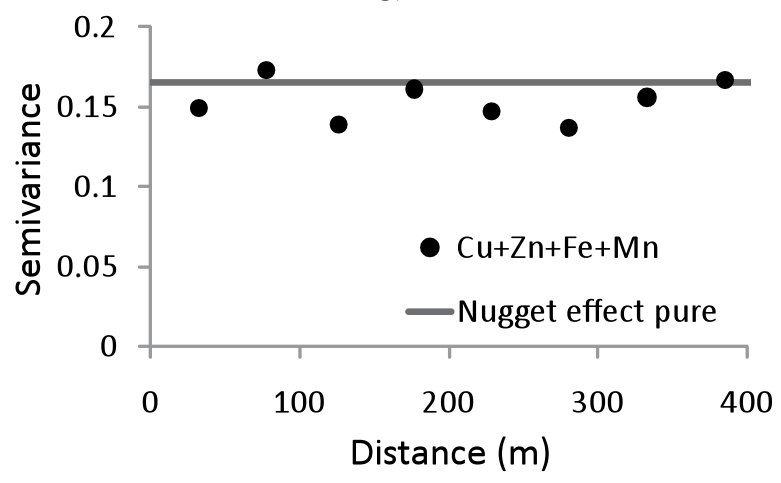

Figure 5. Experimental and fitted indicator semivariogram model. 

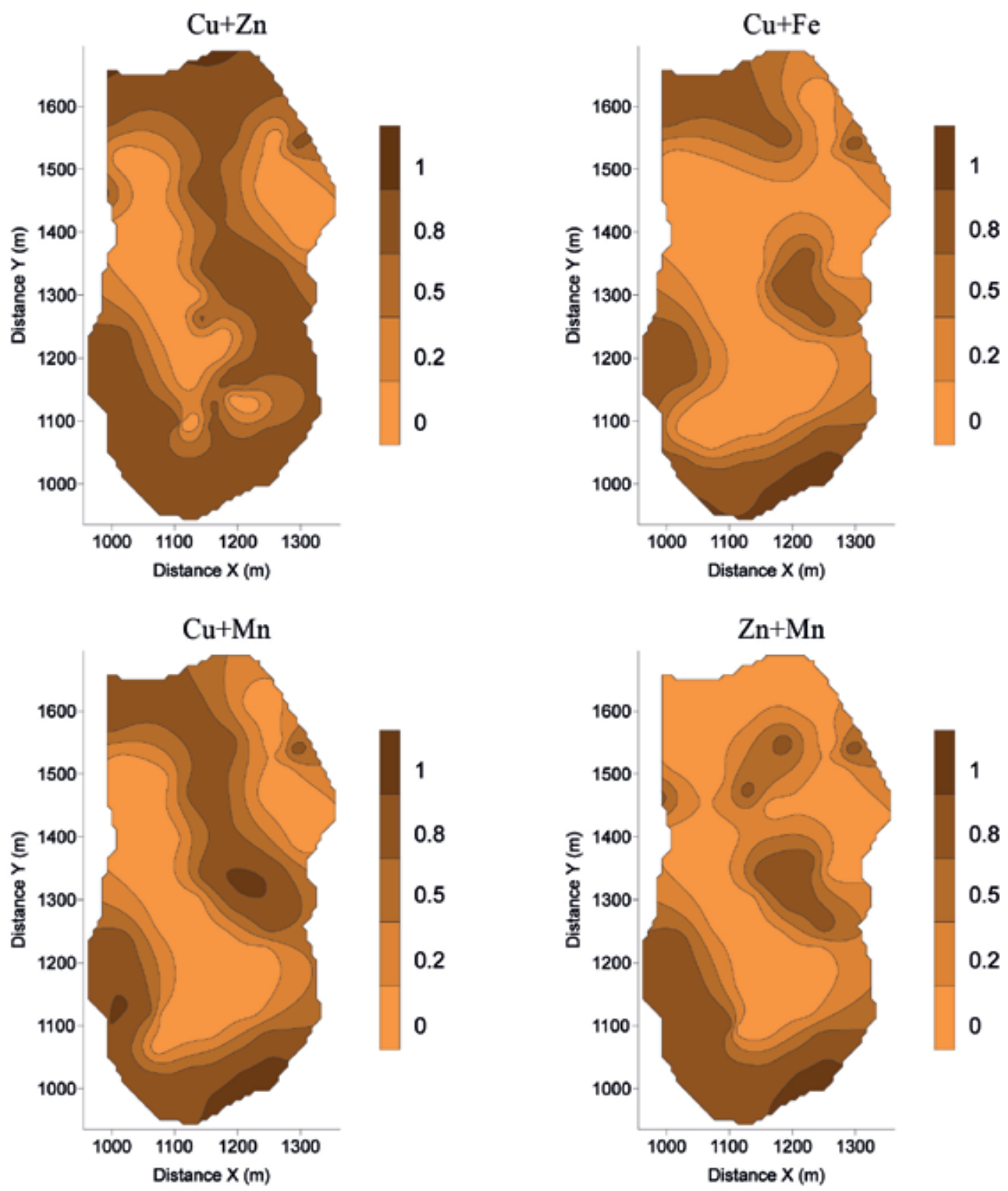

Figure 6. Map of probability for the estimated values obtained by indicator kriging.

important for crop production, using maps obtained with ordinary kriging and indicator kriging. Moreover, the use of indicator kriging favors the use of different threshold values, which must be chosen considering the objective of the study and characteristics of the attributes involved in the study, making it a multipurpose tool for the study of agricultural and environmental attributes.

\section{CONCLUSIONS}

1. The analysis of individual and indicator semivariograms showed low ratio between the values of nugget effect $\left(\mathrm{C}_{0}\right)$ and sill $\left(\mathrm{C}_{0}+\mathrm{C}_{1}\right)$.
2. The maps of spatial variability obtained with indicator kriging have common areas of probability, demonstrating the efficiency of this methodology for determining specific areas of management.

3. The use of indicator kriging using as reference the average value was shown to be effective for joint analysis of micronutrients $(\mathrm{Cu}, \mathrm{Fe}, \mathrm{Zn}$ e $\mathrm{Mn})$, particularly because these elements showed significant correlation.

\section{ACKNOWLEDGEMENTS}

The authors are grateful to the Ministerio de Asuntos Exteriores y de Cooperación (MAEC-AECID) 
from Spain by the granting of scholarships for $\mathrm{PhD}$ studies. This work has been funded by Ministerio de Educación y Ciencia, within the framework of research project CGL2005-08219-C02-022, co-funded by the Galician government Xunta de Galicia, within the framework of research project PGIDIT06PXIC291062PN and by the European Regional Development Fund (ERDF).

\section{REFERENCES}

ABREU, C.A.; RAIJ, B. van; ABREU, M.F.; ANDRADE, J.C. Efficiency of nutrients extractants for determinate of availability copper. Communication in Soil Science and Plant Analysis, v.27, p.763, 1996.

ALLOWAY, B.J. Heavy metals in soils. London: Blackie Academic \& Professional, 1995, 368p.

ASSUMPÇÃO, R.A.B.; URIBE-OPAZO, M.A.; GODOY, E.; JOHANN, J.A. Uso da krigagem indicatriz na avaliação da probabilidade da produtividade de soja segundo os padrões regional, estadual e nacional. Acta Scientiarum Agronomy, v.29, p. 165-171, 2007.

ATKINSON, P.M.; LLOYD, C.D. Mapping Precipitation in Switzerland with Ordinary and Indicator Kriging. Journal of Geographic Information and Decision Analysis, v.2, p.65-76, 1998.

CAHN, M.D.; HUMMEL, J.W.; BROUER, B.H. Spatial analysis of fertility for site-specific crop management. Soil Science Society of America Journal, v.58, p.1240-1248, 1994.

CAMBARDELLA, C.A.; MOORMAN, T.B.; NOVAK, J.M.; PARKIN, T.B.; KARLEN, D.L.; TURCO, R.F.; KONOPKA, A.E. Field-scale variability of soil properties in Central Iowa Soil. Soil Science Society of America Journal, v.58, p.15011511, 1994

CARVALHO, J.R.P.; SILVEIRA, P.M.; VIEIRA, S.R. Geoestatística na determinação da variabilidade espacial de características químicas do solo sob diferentes preparos. Pesquisa Agropecuária Brasileira, v.37, p.1151-1159, 2002.

CARVALHO, J.R.P.; VIEIRA, S.R. Avaliação e comparação de estimadores de krigagem para variáveis agronômicas: uma proposta. Brasília: EMBRAPA, 2001, 21p.

CHILÈS, J.P.; DELFINER, P.. Geostatistics: Modelling Spatial Uncertainty. Toronto: A Wiley-Intercience Publication, 1999. $695 \mathrm{p}$.

COUTO, E.G.; KLANT, E. Variabilidade especial de micronutrients em solo sob pivô central no sul do Estado de Mato Grosso. Pesquisa Agropecuária Brasileira, v.34, p.2321$2329,1999$.

DIODATO, N., CECCARELLI, M., Multivariate indicator kriging approach using a GIS to classify soil degradation for
Mediterranean agricultural lands. Ecological Indicators, v.4, p.177-187, 2004

FAO. Wold Referencial Base for Soil Resources. $\mathrm{n}^{\circ}$ 84, FAO, ROMA, 1998. 88p. (Colección Worl soil Resources Reports)

GOLDEN SOFTWARE. SURFER for windows. Realese 7.0. Contouring and 3D surface mapping for scientist's engineers: User's guide. New York: Golden Software, 1999. 619p.

GOMES, F.P., GARCIA, C.H. Estatística aplicada a experimentos agronômicos e florestais. Piracicaba: FEALQ, 2002.309p.

GOOVAERTS, P. Geostatistics for natural resources evaluation. New York, Oxford University Press, 1997. 496p.

GOOVAERTS, P. Geostatistics in soil science: state-of-art and perspectives. Geoderma, v.89, p.1-45, 1999

GREGO, C.R.; VIEIRA, S.R. Variabilidade espacial de propriedades físicas do solo em uma parcela experimental. Revista Brasileira de Ciência do Solo, v.29, p.169-177, 2005.

ISAAKS, E.H.; SRIVASTAVA R.M. An introduction to applied geostatistics. New York: Oxford University Press, 1989. 560p.

KRIGE, D.G. A statistical approach to some basic mine evaluation problems on the witwatersrand. Journal of South African Institution of Minning an Mettalurgy, v.52, p.119139, 1951

LIN, Y.P., CHANG, T.K., SHIH, C.W., TSENG, C.H.. Factorial and indicator kriging methods using a geographic information system to delineate spatial variation and pollution sources of soil heavy metals. Environmental Geology, v.42, p.900-909, 2002.

LINDSAY, W.L.; NORVELL, W.A. Development of a DTPA soil test for zinc, iron, manganese and copper. Soil Science Society of America Journal, v.42, p.421-428, 1978.

LIU, X.M.; XU, J.M.; ZHANG, M.K.; HUANG, J.H.; SHI, J.C.; YU, X.F. Application of geostatistics and GIS technique to characterize spatial variabilities of bioavailable micronutrients in paddy soil. Environmental Geology, v.46, p.189-194, 2004.

LYON, S.W.; LEMBO, A.L.; WALTER, M.T.; STEENHUIS, T.S. Defining probability of saturation with indicator kriging on hard and soft data. Advances in Water Resources, v.29, p.181-193, 2006.

MATHERON, G. Principles of geostatistics. Economic Geology, v.58, p.1246-1266, 1963.

MCBRATNEY, A.B. Geostatistical soil survey. 1984. 250p. Ph.D. Thesis - Department of Soil Science, University of Aberdeen.

MONTGOMERY, E.G. Experiments in wheat breeding: experimental error in the nursery and variation in nitrogen 
and yield. Washington, D.C.: U.S. Department of Agriculture, 1913. 61p. (Bur. Plant Indust. Bul., 269).

MOTOMIYA, A.V.A.; CORÁ, J.E.; PEREIRA, J.T. Uso de krigagem indicatriz na avaliação de indicadores de fertilidade do solo. Revista Brasileira de Ciência do Solo, v.30, p.485496, 2006.

PEGORARO, R.F.; SILVA, I.R.; NOVAIS, R.F.; MENDONÇA, E.S.; GEBRIM, F.O.; MOREIRA, F.F. Fluxo difuso e biodisponibilidade de zinco, cobre, ferro e manganês no solo: influência da calagem, textura do solo e resíduos vegetais. Revista Brasileira de Ciência do Solo, v.30, p.859-868, 2006.

RAIJ, B. van; CANTARELLA, H.; QUAGGIO, J.A.; FURLANI, A.M.C. Recomendações de adubação e calagem para o Estado de São Paulo. Campinas: Instituto Agronômico, 1996, 285p. (Boletim 100)

SIQUEIRA, G.M.; VIEIRA, S.R.; CEDDIA, M.B. Variabilidade espacial de atributos físicos do solo determinados por métodos diversos. Bragantia, v.67, p.203-211, 2008.

SMITH, J.L.; HALVORSON, J.J.; PAPENDICK, R.I. Using multiple-variable indicator kriging for evaluating soil quality. Soil Science Society of America Journal, v.57, p.743-749, 1993.

SMITH, L.H. Plot arrangement for variety experiment with corn. Proceedings American Society of Agronomy, v.1, p.8489, 1910.

TOLOSANA-DELGADO, R.; PAWLOWSKY-GLAHN, V.; EGOZCUE, J.J.; van der BOOGAART, K.G. A compositional approach to indicator kriging. Proceedings of IAMG'05: GIS and Spatial Analysis, v.1, 651-656, 2005.
ULLOA GUITIÁN, M. Aplicación de la geoestadística al estudio de la fertilidad del suelo. Tesis doctoral, Universidade Da Coruña. 2002, 440p.

ULLOA GUITIÁN, M.; ABREU, C.A.; PAZ GONZÁLEZ, A. Disponibilidad de macro y micronutrientes en un suelo de cultivo de Mabegondo (La Coruña). Cadernos do Laboratorio Xeolóxico de Laxe, v.26, p.243-254, 2001.

VIEIRA, S.R. Geoestatística em estudos de variabilidade espacial do solo. In: NOVAIS, R.F., ALVAREZ, V.H., SCHAEFER, G.R. (Ed.). Tópicos em Ciência do Solo. Viçosa: Sociedade Brasileira de Ciência do Solo, 2000. v.1, p. 1-54.

VIEIRA, S.R.; MILLETE, J.; TOPP, G.C.; REYNOLDS, W.D. Handbook for geoestatistical analysis of variability in soil and climate data. In: ALVAREZ, V.V.H.; SCHAEFER, C.E.G.R.; BARROS, N.F.; MELLO, J.W.V.; COSTA, J.M. Tópicos em Ciência do Solo. Viçosa: Sociedade Brasileira de Ciência do Solo, 2002. v.2, p.1-45.

WHITE, J.G.; ZASOSKI, R.J. Mapping soil micronutrients. Field Crops Research, v.60, p.11-26, 1999.

YU-PIN, L.; BAI-YOU, C.; GUEY-SHIN, S.; TSUN-KUO, C. Combination a finite mixture distribution model with indicator kriging to delineated and map the spatial patterns of soil heavy metal pollution in Chunghua Country, central Taiwan. Environmental Pollution, v.158, p.235-244, 2010.

ZANÃO JÚNIOR, L.A.; LANA, R.M.Q.; GUIMARÃES, E.C. Variabilidade espacial do $\mathrm{pH}$, teores de matéria orgânica e micronutrientes em profundidades de amostragem num Latossolo Vermelho sob semeadura direta. Ciência Rural, v.37, p.1000-1007, 2007. 